\title{
Electrochemotherapy treatment of oral extramedullary plasmacytoma of the tongue: a retrospective study of three dogs
}

\author{
Rúbia Monteiro de Castro Cunha ${ }^{*}$ Gleidice Eunice Lavalle ${ }^{1}$ \\ Carla Emanuela Tertuliano Caires ${ }^{1}$ Roberto Baracat de Araújo ${ }^{1}$
}

'Departamento de Clínica e Cirurgia Veterinária, Escola de Veterinária, Universidade Federal de Minas Gerais (UFMG), Belo Horizonte, MG, Brasil. E-mail: rubiamcc@gmail.com. "Corresponding author.

\begin{abstract}
Extramedullary plasmacytomas (EPS) are responsible for $2.5 \%$ of neoplasms in dogs. They are solitary, smooth, elevated, pink or red nodules, of 1 to $2 \mathrm{~cm}$ in diameter. Cutaneous and oral extramedullary plasmacytomas in dogs are usually benign tumors, treated with local therapies. Prognosis is generally good. Recurrence and metastatic rates are low. Electrochemotherapy is a local treatment that combines chemotherapy and electroporation and shows objective responses of $70 \%$ to $94 \%$ with few local and systemic side effects. This scientific communication has the objective to report treatment of three canine patients with oral extramedullary plasmacytoma. Nodules were located on the tongue and patients were submitted to one or two electrochemotherapy sessions, which preserved the tongue without mutilation and cured the patients.
\end{abstract}

Key words: cancer, electrochemotherapy, dog, plasmacytoma, lingual.

Eletroquimioterapia no tratamento de plasmocitoma extramedular oral na língua: estudo retrospectivo de três cães

RESUMO: Plasmocitomas extramedulares (PE) são responsáveis por 2,5\% das neoplasias em cães. São nódulos solitários, lisos, elevados, rosados ou avermelhados, de 1 a $2 \mathrm{~cm}$ de diâmetro. O plasmocitoma extramedular cutâneo e oral em cães é um tumor tipicamente benigno tratado com terapias locais. O prognóstico geralmente é bom. As taxas de recorrência e metástase são baixas. A eletroquimioterapia é um tratamento local que combina quimioterapia e eletroporação e mostra respostas objetivas entre 70 a $94 \%$ com poucos efeitos colaterais locais e sistêmicos. Esta comunicação científica teve como objetivo relatar o tratamento de três pacientes caninos com plasmocitoma extramedular oral com lesões localizadas na língua submetidos a uma ou duas sessões de eletroquimioterapia, o que permitiu a manutenção da língua sem mutilação e proporcionou a cura dos pacientes.

Palavras-chave: câncer, eletroquimioterapia, cão, plasmocitoma, lingual.

Solitary collections of monoclonal plasmacytomas may originate from soft tissues and are called extramedullary plasmacytomas (EP) (VAIL, 2013). $\mathrm{EP}$ are responsible for $2.5 \%$ of all neoplasms in dogs and are more common in middle-aged to older dogs (average 8 to 10 years old) (RAKICH et al., 1989; CLARCK et al., 1992; PLATZ et al., 1999; CANGUL et al., 2002; KUPANOFF et al., 2006; WRIGHT et al., 2008; STERNBERG et al., 2009).

In a major study that evaluated 751 canine EPs, common affected sites were skin $(86 \%)$, mucous membranes of the oral cavity and lips $(9 \%)$, and rectum and colon (4\%). Other organs, including stomach, small intestines, spleen, genitalia and eyes, represented $1 \%$ of plasmacytomas (KUPANOFF et al., 2006; STERNBERG et al., 2009).
Cutaneous and mucocutaneous plasmacytomas are generally smooth, elevated, pinkish or red solitary nodules ranging from 1 to $2 \mathrm{~cm}$ (RAKICH et al., 1989; CLARK et al., 1992; STENBERG et al., 2009; VAIL, 2013). On occasion, dogs may develop multiple tumors or polypoid and ulcerated tumors (RAKICH et al., 1989; CLARCK et al., 1992; STERNBERG et al., 2009). Clinical signs are unusual for most dogs with mucocutaneous EP; although, a tumor mass and oral bleeding may be seen (RAKICH et al., 1989; WRIGHT et al., 2008; STERNBERG et al., 2009).

Extramedullary plasmacytoma is frequently diagnosed with cytology or immunohistochemistry (VAIL, 2013). EP histopathological findings show nonencapsulated, locally aggressive tumors (PLATZ et al., 
1999; STERNBERG et al., 2009). Cutaneous and oral EP in dogs are typically benign tumors, easily treated with local therapies (VAIL, 2013). Radiotherapy is rarely used for non-resectable cases, including plesiotherapy with strontium-90 for a lingual plasmacytoma in a dog (WARE \& GIEGER, 2011; VAIL, 2013). Prognosis for solitary plasmacytomas is usually good. Cutaneous and mucocutaneous plasmacytomas are generally cured after surgical resection (PLATZ et al., 1999; CANGUL et al., 2002; WRIGHT et al., 2008; VAIL, 2013). In large case compilations, local recurrence rate was approximately $5 \%$ and regional lymph node or distant metastasis occurred in only seven of 349 cases (2\%) (BAER et al., 1989; RAKICH et al., 1989; CLARK et al., 1992; PLATZ et al., 1999; CANGUL et al., 2002; VAIL, 2013).

Electrochemotherapy is a local treatment that combines chemotherapy and electroporation (SERSA et al., 2006). Electroporation enhances plasma membrane permeability using external electric pulses (SILVA, 2011). Drug dosages may be reduced, since electroporation causes an increase in drug efficacy where the electric pulses are applied, reducing systemic side effects (LARKIN et al., 2007). Electrochemotherapy has been reported as an oncological treatment with objective responses ranging from 70 to $94 \%$ in cutaneous, subcutaneous and mucocutaneous lesions, with few systemic and local side effects (MIR et al., 1997; MARTY et al., 2006; QUAGLINO et al., 2008; KODRE et al., 2009; SPUGNINI et al., 2009; SILVEIRA et al., 2010; SPUGNINI et al., 2010; SERSA et al., 2012).

This scientific communication has the objective ofreportingthreecanineoral extramedullaryplasmacytomas that were treated only with electrochemotherapy. Therefore, three dogs with multiple or solitary oral extramedullary plasmacytomas were included in this study.

Age, breed, number of nodules, nodule size and number of electrochemotherapy treatment sessions are registered in table 1 . All lesions were located on the tongue and all patients were submitted to at least one treatment session. During anesthetic procedure, a significant nodule fragment was collected for incisional biopsy. Tumors were fixed on $10 \%$ buffered formalin and submitted for histopathological analysis. Oral extramedullary plasmacytoma was the histopathologic diagnosis in all cases. Post treatment protocol included amoxicillin with clavulanic acid for 10 days (22 $\mathrm{mg} \mathrm{kg}^{-1}$ every 12 hours), tramadol for four days ( $4 \mathrm{mg} \mathrm{kg}^{-1}$ every 8 hours), prednisone for four days ( $1 \mathrm{mg} \mathrm{kg}^{-1}$ every 12 hours) and topic cleaning with chlorhexidine gluconate $0.12 \%$.

Electrochemotherapy treatments were performed using an electroporator device developed by the Department of Electric Engineering of Engineering School of Universidade Federal de Minas Gerais. This electroporator produces bipolar square wave pulses, $100 \mu$ seconds duration, $5 \mathrm{kHZ}$ frequency and $1300 \mathrm{~V}$ $\mathrm{cm}^{-1}$. Electric pulses were delivered through needle electrodes five minutes after bleomycin administration (four needles in a row, two rows, $5 \mathrm{~mm}$ apart). Bleomycin was the chemotherapeutic drug used in a dosage of $15000 \mathrm{UI} \mathrm{m}^{-2}$, intravenously.

Dogs were examined weekly until lesions healed and every three months thereafter. Animals showed tongue edema where lesions were located. All animals recovered without major incidents and started feeding again the day after the procedure (soft foods at first). Time to complete healing varied between 14 days for the patients treated with one session and 40 days for the patient treated with two sessions (Figure 1). Interval between sessions was 21 days. To the day this note was submitted for publication, animals were healthy, with a disease-free interval and overall survival between eight months for the patient with multiple lesions, one year and three months for the patient treated with two sessions and two years and 10 months for the patient with one lesion treated with one session.

Electrochemotherapy was indicated because other treatment modalities would be associated with significant morbidity. Surgical excision of nodules would require partial or total glossectomy due to tongue vascularization. Radiotherapy was not available in Brazil at the time and it is cost prohibitive.

Extramedullary plasmacytoma usually has a favorable prognosis, as opposed to multiple myeloma.

Table 1 - Number of lesions and number of treatment sessions for each patient.

\begin{tabular}{|c|c|c|c|c|}
\hline Breed & Age & $\begin{array}{c}\text { Number of } \\
\text { lesions }\end{array}$ & $\begin{array}{c}\text { Lesion volume (calculated with the formula: } \mathrm{ab}^{2} \pi / 6 \text {, in } \\
\text { which a is the largest diameter, } \mathrm{b} \text { is the diameter } \\
\text { perpendicular to a) }\end{array}$ & $\begin{array}{c}\text { Number of } \\
\text { sessions }\end{array}$ \\
\hline Cocker spaniel & 6 years & 1 & $0.5 \mathrm{~cm}^{3}$ & 1 \\
\hline Yorkshire & 8 years & 1 & $6.3 \mathrm{~cm}^{3}$ & 2 \\
\hline Belgium Shepherd & 8 years & 4 & $0,1 \mathrm{~cm}^{3}$ (each) & 1 \\
\hline
\end{tabular}

Ciência Rural, v.47, n.12, 2017. 


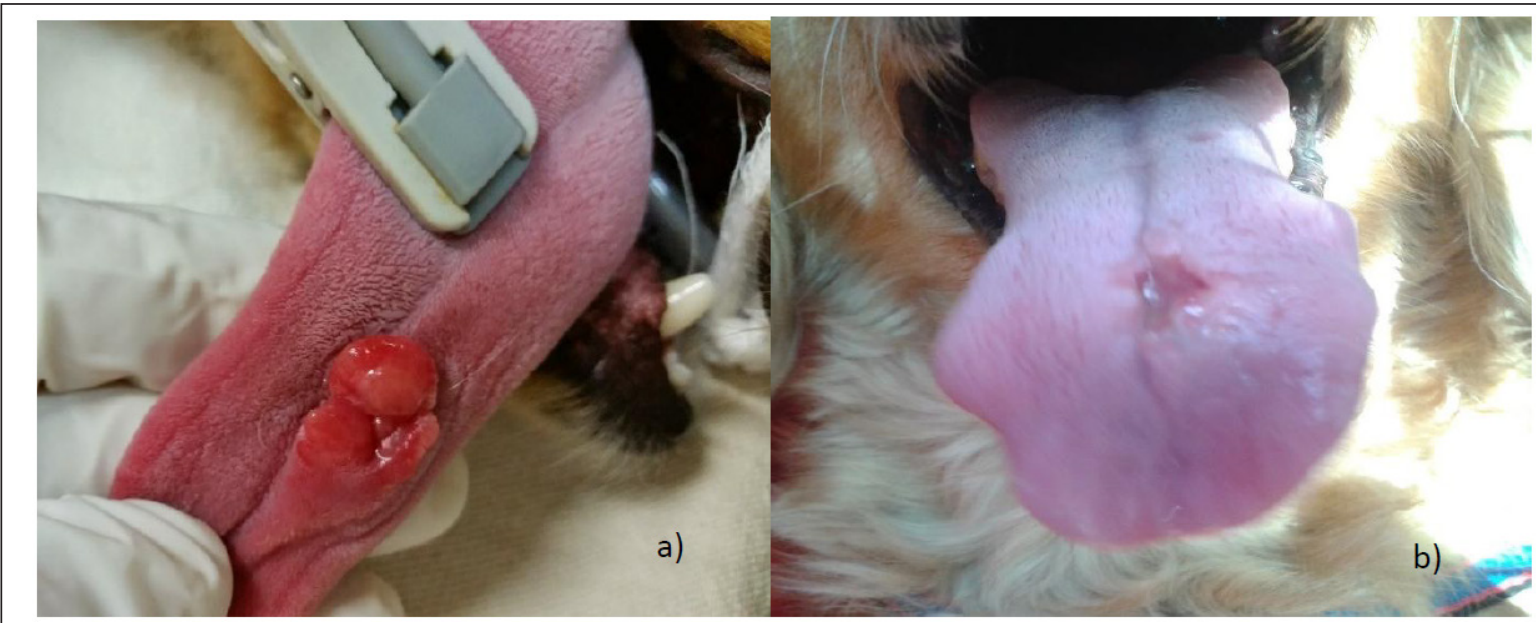

Figure 1 - a) Oral extramedullary plasmacytoma of the tongue before treatment (cocker spaniel patient; b) Complete resolution of the nodule, with lingual scar 14 days after treatment.

EPs are normally locally invasive, with a low metastatic rate, and complete surgical excision is curative (RAKICH et al., 1989; CLARCK et al., 1992; CANGUL et al., 2002; STERNBERG et al., 2009).

Electrochemotherapy was an effective local treatment. It allowed tongue preservation, without mutilation, and patients were considered cured. Tongue is an essential organ for food intake and water consumption, and its preservation allowed maintenance of patient life quality.

\section{DECLARATION OF CONFLICTING INTERESTS}

There are no conflicts of interest.

\section{REFERENCES}

BAER, K.E. et al. Cutaneous plasmacitoma in dogs: a morphologic and immunohistochemical study. Veterinary Pathology, v.26, p.216-221, 1989. Available from: <https:/www.ncbi.nlm.nih.gov/ pubmed/2669312>. Accessed: Feb. 07, 2017.

CANGUL, I.T. et al. Clinico-pathological aspects of canine cutaneous and mucocutaneous plasmacytomas. Journal of veterinary medicine. A, Physiology, pathology, clinical medicine, v. 49, n. 6, p. 307-312, 2002. Available from: <https://www.ncbi.nlm.nih.gov/pubmed/12227474>. Accessed: Feb. 07, 2017. doi: 0931-184X/2002/4906-0307.

CLARK, G.N. et al. Extramedullary plasmacytomas in dogs: results of surgical excision in 131 cases. Journal American Animal Hospital Association, v.28, p.105-111, 1992. Available from: <http://onlinelibrary. wiley.com/doi/10.1111/j.1748-5827.1993.tb02620.x/abstract>. Accessed: Feb. 07, 2017. doi: 10.1111/j.1748-5827.1993.tb02620.x.

KUPANOFF, P.A. et al. Colorectal plasmacytomas: a retrospective study of nine dogs. Journal American Animal Hospital Association, v.42, n.1, p.37-43, 2006. Available from: <https://www.ncbi. nlm.nih.gov/pubmed/16397193>. Accessed: Feb. 07, 2017. doi: 10.5326/0420037

LARKIN, J.O. et al. Electrochemotherapy - Aspects of preclinical development and early clinical experience. Annals of Surgery, v.245, p.469-479, 2007. Available from: <https://www.ncbi.nlm.nih. gov/pubmed/17435555>. Accessed: Feb. 07, 2017. doi: 10.1097/01. sla.0000250419.36053.33.

KODRE, V. et al. Electrochemotherapy compared tosurgery for treatment of canine mast cell tumours. In Vivo, v.23, p.55-62, 2009. Available from: <http://onlinelibrary.wiley.com/doi/10.1111/ vco.12217/full>. Accessed: Feb. 07, 2017. doi: 10.1111/vco.12217.

MARTY, M. et al. Electrochemotherapy - An easy, highly effective and safe treatment of cutaneous and subcutaneous metastases: results of ESOPE (European Standard Operating Procedures of Electrochemotherapy) study. European Journal of Cancer, Suppl., n.4,p.3-13, 2006. Available from: $<$ http://www.ejcancersupplements. com/article/S1359-6349(06)00186-8/abstract>. Accessed: Feb. 07, 2017. doi: 10.1016/j.ejcsup.2006.08.002.

MIR, L.M. et al. First clinical trial of cat soft tissue sarcomas treatment by electrochemotherapy. British Journal of Cancer, v.76, p.1617-1622, 1997. Available from: <https://www.ncbi.nlm.nih.gov/ pmc/articles/PMC2228194/?page=1>. Accessed: Feb. 07, 2017.

PLATZ, S.J. et al. Prognostic value of histopathological grading in canine extramedullary plasmacytomas. Veterinary Pathology, v.36, n.1, p.23-27, 1999. Available from: <https:/www.ncbi.nlm. nih.gov/pubmed/9921752>. Accessed: Feb. 07, 2017.

QUAGLINO, P. et al. Electrochemotherapy with intravenous bleomycin in the local treatment of skin melanoma metastases. Annals of Surgical Oncology, v.15, p.2215-2222, 2008. Available from: $<$ https://www.ncbi.nlm.nih.gov/pubmed/18498012>. Accessed: Feb. 07, 2017. doi: 10.1245/s10434-008-9976-0.

RAKICH, P.M. et al. Mucocutaneous plasmacytomas in dogs: 75 cases (1980-1987). Journal of the American Veterinary Medical

Ciência Rural, v.47, n.12, 2017. 
Association, v.194, n.6, p.803-810, 1989. Available from: <https:// www.ncbi.nlm.nih.gov/pubmed/2466821>. Accessed: Feb. 07, 2017.

SERSA, G. et al. Electrochemotherapy of tumours. Radiology and Oncology, v.40, n.3, p.163-174, 2006. Available from: $<\mathrm{http}: / /$ www.radioloncol.com/index.php/ro/article/view/1258/1018>. Accessed: Feb. 07, 2017.

SERSA, G. et al. Electrochemotherapy of chest wall breast cancer recurrence. Cancer Treatment Reviews, v.38, p.379-386, 2012. Available from: <https://www.ncbi.nlm.nih.gov/pubmed/21856080>. Accessed: Feb. 07, 2017. doi: 10.1016/j.ctrv.2011.07.006.

SILVA, M.D. Desenvolvimento e avaliação de um gerador programável de pulsos monofásicos de campo elétrico para eletroporação. 2011. 86f. Dissertação (Mestrado em Engenharia Biomédica) - Programa de Pós-graduação em Engenharia Biomédica, COPPE, da Universidade Federal do Rio de Janeiro, Rio de Janeiro, RJ.

SILVEIRA, L.M.G. et al. Utilização de eletroquimioterapia em neoplasias de origem epitelial ou mesenquimal localizadas em pele ou mucosas de cães. Brazilian Journal of Veterinary Research and Animal Science, v.47, n.1, p.55-66, 2010. Available from: <http:// www.revistas.usp.br/bjvras/article/view/26849>. Accessed: Feb. 07, 2017. doi: 10.11606/issn.1678-4456.bjvras.2010.26849.

SPUGNINI, E.P. et al. Electrochemotherapy for the treatment of squamous cell carcinoma in cats: a preliminary report. Veterinary Journal, v.179, p.117-120, 2009. Available from: < https://www. ncbi.nlm.nih.gov/pubmed/17904882>. Accessed: Feb. 07, 2017. doi: 10.1016/j.tvj1.2007.08.011.

SPUGNINI, E.P. et al. Electrochemotherapy treatment for bilateral pleomorphic rhabdomyosarcoma in a cat. Journal of Small Animal Practice, v.51, p.330-332, 2010. Available from: <http://onlinelibrary. wiley.com/doi/10.1111/j.1748-5827.2010.00913.x/abstract>. Accessed: Feb. 07, 2017. doi: 10.1111/j.1748-5827.2010.00913.x.

STERNBERG, R. et al. Extramedullary and solitary osseous plasmacytomas in dogs and cats. Veterinary Medicine, v.104, p.477480, 2009. Available from: <http://veterinarymedicine.dvm360.com/ extramedullary-and-solitary-osseous-plasmacytomas-dogs-and-cats $>$. Accessed: Feb. 07, 2017.

VAIL, D.M. Hematopoietic tumors. In: WITHROW, S.J.; MACEWEN, E.G. Withrow and MacEwen's small animal clinical oncology. Philadelfia: Saunders, 2013. 846p.

WARE, K.; GIEGER, T. Use of strontium-90 plesiotherapy for the treatment of a lingual plasmacitoma in a dog. Journal of Small Animal Practice, v.52, p.220-223, 2011. Available from: $<$ https:// www.ncbi.nlm.nih.gov/pubmed/21906066>. Accessed: Feb. 07, 2017. doi: 10.1111/j.1748-5827.2011.01057.x.

WRIGHT, Z.M. et al. Survival data for canine oral extramedullary plasmacitoma: a retrospective analysis (1996-2006). Journal of the American Animal Hospital Association, v.44, p.75-81, 2008. Available from: <https:/www.ncbi.nlm.nih.gov/pubmed/18316443>. Accessed: Feb. 07, 2017. doi: 10.5326/0440075. 